\title{
Functioning of public transport systems in the conditions of the COVID-19 pandemic on the example of a selected urbanized area
}

\author{
Ewa Kuliś ${ }^{1 *}$, Bogdan Landowski ${ }^{1}$, and Aleksandr Povareho ${ }^{2}$ \\ ${ }^{1}$ Bydgoszcz University of Science and Technology, Faculty of Mechanical Engineering, Al. Prof. S. \\ Kaliskiego 7, 85-796 Bydgoszcz, Poland \\ ${ }^{2}$ Belarusian National Technical University, 220013 Minsk, Nezavisimosti, 65, Belarus
}

\begin{abstract}
For the unit performing the transport task, it is important to have tools that enable the analysis and forecasting of the system status and facilitate making decisions regarding the control of the process. During the epidemic, many legal solutions were imposed, which forced changes in the process of using public transport. The following article describes the changes and their impact on the situation in Poland.
\end{abstract}

\section{Introduction}

The COVID-19 infectious disease pandemic caused by the SARS-CoV-2 coronavirus. began on November 17, 2019 in the city of Wuhan (China). On March 4, 2020, the first case of the disease was confirmed in Poland [1]. Since then, a number of regulations and changes have been introduced to improve epidemiological safety for users of public transport.

One of the consequences of the COVID-19 pandemic is the fact that many of public transport users have switched to private cars. And this weakened the effects of many years of activities to popularize public transport. The passengers' concerns should be alleviated by the fact that both public transport vehicles and stops are regularly disinfected since the beginning of the pandemic.

Since March, i.e. since the announcement of the COVID-19 pandemic by the WHO, actions are constantly being taken to increase passenger safety. Both buses, trams and bus shelters are regularly washed and disinfected. The disinfection of rolling stock and infrastructure in public transport is an extraordinary precaution and method of counteracting the spread of the SARS-CoV-2 coronavirus, which many Polish cities are putting on today. The bus shelters are washed and disinfected using high-pressure devices with the use of disinfectants (concentrates) added to the water. Additionally, after washing, flat surfaces such as benches, front posts and display cases are disinfected. Due to the pandemic, the average decline in ticket sales - both in public transport and rail - is estimated at over $80 \%$.

The bus shelters are washed and disinfected using high-pressure devices with the use of disinfectants (concentrates) added to the water. In addition, after washing, flat surfaces such as benches, frontal pillars and display cabinets are disinfected.

*Corresponding author: ewa.kulis@pbs.edu.pl 
If it is suspected that a stop could be used by a person infected with coronavirus, e.g. to whom an ambulance or the police or municipal police were called and the temperature was elevated, the stop shelter is then excluded from use and immediately disinfected with stronger disinfectants, which must then be be washed off.

The coronavirus that causes COVID-19 is mainly transmitted by droplets that are released when an infected person coughs, sneezes and exhales. These droplets are too heavy to be airborne, so they quickly fall to floors and surfaces. That is why buses are washed inside and outside with water and detergent and disinfected with an appropriate preparation every day after the end of the transport work. Particular emphasis is placed on the disinfection of elements and surfaces touched by passengers, including handles, handrails and buttons.

Additionally, in public transport vehicles, passengers are required to cover their mouth and nose with protective masks or visors to minimize the spread of dangerous droplets.

Disinfection is an integral part of the daily cleaning of vehicles. During the pandemic, these activities were further intensified. In addition to the daily disinfection, vehicles are ozonated at weekends in many of the Polish transport facilities. It is a several-hour process that can be carried out with less use of the rolling stock. Ozone disinfection is a way to create an almost sterile environment, free from viruses, bacteria, allergens and unpleasant odours.

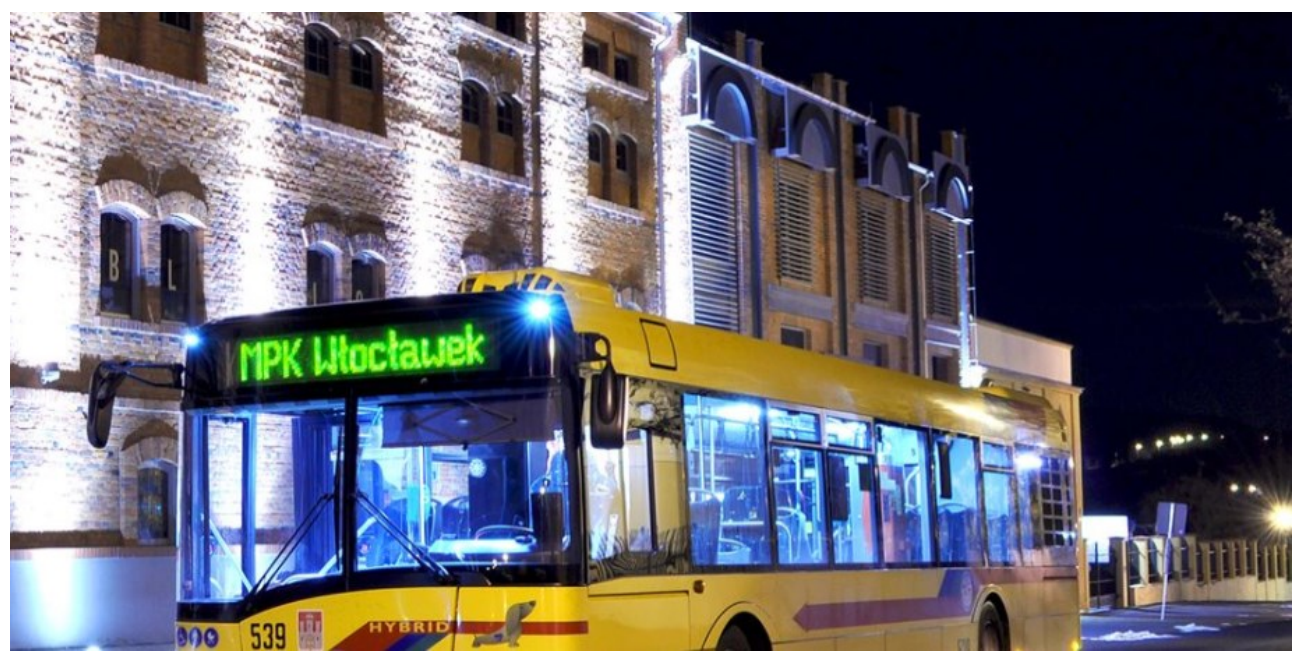

Fig. 1. Disinfection of buses in Gdynia. Photo Miejskie Przedsiębiorstwo Komunikacyjne Sp. z o.o in Włocławek [20].

Due to the red zone in force, the following changes to public transport were introduced on October 17, 2020.

The limit of passengers in public transport vehicles has been reduced. As many people can travel in vehicles at the same time, amounting to $30 \%$ of the total number of seats and standing places, while only half of the seats may be occupied. It is forbidden to occupy designated seats until further notice. Additional patrols will monitor passenger limits, especially during times of increased communication, to ensure the safety and health of passengers.

Due to the introduced passenger limit, during rush hours, reserve vehicles leave for encore courses, duplicating those provided for in the timetables. Articulated vehicles are introduced in selected courses to replace those of standard length.

The sale of tickets by vehicle drivers has also been suspended until further notice.

The decline in attendance in large and smaller cities is similar. In Warsaw, it was estimated that the revenues from the sale of tickets will decrease by PLN 200 million by the 
end of the year, which covers the expenses - up to $25 \%$. The authorities of many Polish cities have allowed the suspension of season tickets. At the worst moment (March, April), ticket sales decreased by $90 \%$.

The financial situation is not easy in any of the local governments. They have to cope with enormous costs. Unforeseen expenses related to the disinfection of the rolling stock, personal protective equipment, enclosure fencing, installation of liquid dispensers in transfer junctions. It is estimated that full disinfection of one bus costs PLN 700-1000 per month. To facilitate the travel of passengers, many of the carriers have decided to install ticket machines and payment card readers, which also generated additional costs.

The regulations regarding the filling limits of communication vehicles during the pandemic have been changed more than 10 times and they are very difficult to enforce.

As a result of the decisions taken at the government level, the greatest challenge today is to restore public confidence in collective transport. In addition, the deterioration of the general economic situation will probably result in the necessity to increase ticket prices (in recent years, ticket prices in many cities have been significantly lowered or kept at a constant level).

It should be remembered that regardless of the pandemic, public transport will play a key role in decarbonisation and emission reduction. However, the complexity of all phenomena and events does not allow for simple prediction. The new doctrine of "black swans" presupposes the need to prepare for sudden events that introduce a lot of haos. On the other hand, individual transport can be limited in many ways, for example by offering free 6-month travel only between work and home or by increasing prices in paid parking zones [2-5].

\section{Exploration processes}

The effectiveness of the enterprise, measured by economic results, is directly influenced by both downtime of technological devices caused by failure of their components and planned maintenance and reconstruction of the utility (repair) potential [6]. Due to the unforeseen epidemiological situation, many of the transport companies began to generate much higher costs due to the necessity to maintain sanitary requirements, disinfection etc., and to bring lower profits due to the decrease in the number of users [7-9].

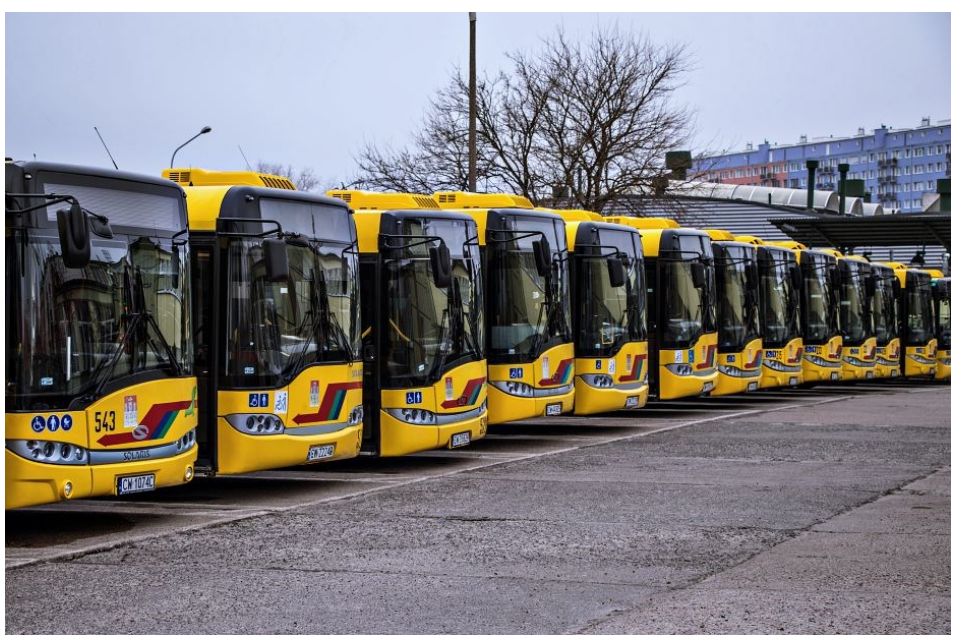

Fig. 2. Camp MPK Włocławek [20].

Based on the data from MPK Włocławek, a drastic decrease in the number of passengers can be clearly seen compared to individual quarters in 2019 
Table 1. Transport work performed by MPK Sp. z o.o. in Włocławek.

\begin{tabular}{|l|r|r|r|r|r|r|r|}
\hline & $\begin{array}{l}\text { Quarter } \\
\text { I 2019 }\end{array}$ & $\begin{array}{c}\text { Quarter } \\
\text { II 2019 }\end{array}$ & \multicolumn{1}{|c|}{$\begin{array}{l}\text { Quarter } \\
\text { III 2019 }\end{array}$} & $\begin{array}{l}\text { Quarter } \\
\text { IV 2019 }\end{array}$ & \multicolumn{1}{|c|}{$\begin{array}{c}\text { Quarter } 2020 \\
\text { II 2020 }\end{array}$} & \multicolumn{1}{|c|}{$\begin{array}{l}\text { Quarter } \\
\text { III 2020 }\end{array}$} \\
\hline $\begin{array}{l}\text { number of } \\
\text { vehicle } \\
\text { kilometers } \\
\text { made, incl }\end{array}$ & 889362 & 918137 & 950726 & 949509 & 935655,4 & 960942,15 & 979279,4 \\
\hline on city lines & 861540,9 & 891892,65 & 924412,5 & 916964 & 910231 & 941608,45 & 954723,05 \\
\hline $\begin{array}{l}\text { suburban } \\
\text { lines }\end{array}$ & 16260,1 & 16012,35 & 16714,5 & 16241 & 16234,4 & 15854,1 & 16867 \\
\hline $\begin{array}{l}\text { ordered and } \\
\text { other } \\
\text { transport }\end{array}$ & 11561 & 10232 & 8265 & 28724 & 9190 & 3479,6 & 7689,35 \\
\hline including & 72014 & 73752 & 76531 & 73353 & 72866 & 75617 & 78709 \\
\hline $\begin{array}{l}\text { number of } \\
\text { passengers, } \\
\text { incl }\end{array}$ & 2742038 & 2699468 & 2781706 & 2743067 & 2364166 & 970387 & 1756673 \\
\hline $\begin{array}{l}\text { on city lines } \\
\text { on }\end{array}$ & 2692416 & 2659334 & 2763341 & 2696074 & 2334311 & 969897 & 1742918 \\
\hline $\begin{array}{l}\text { on } \\
\text { commissione } \\
\text { d and other } \\
\text { transport }\end{array}$ & 45640 & 34965 & 13510 & 42665 & 29855,00 & 490 & 13755 \\
\hline
\end{tabular}

The data analysis shows that the length of communication routes is $149.05 \mathrm{~km}$ (as of April 2019). The length of communication lines is approximately $311.90 \mathrm{~km}$ (as of April 2019). The number of vehicle kilometers performed in individual quarters in 2019 and 2020 are at a similar level (in 2020 they were enforced by sanitary regulations limiting the number of passengers on public transport). The number of employees in the company remained at a similar level, while the number of passengers decreased drastically, as shown in the chart below.

Due to the fact that children have remote learning most of the time, the forecasts of the number of passengers for the fourth quarter of 2020 are also much lower.

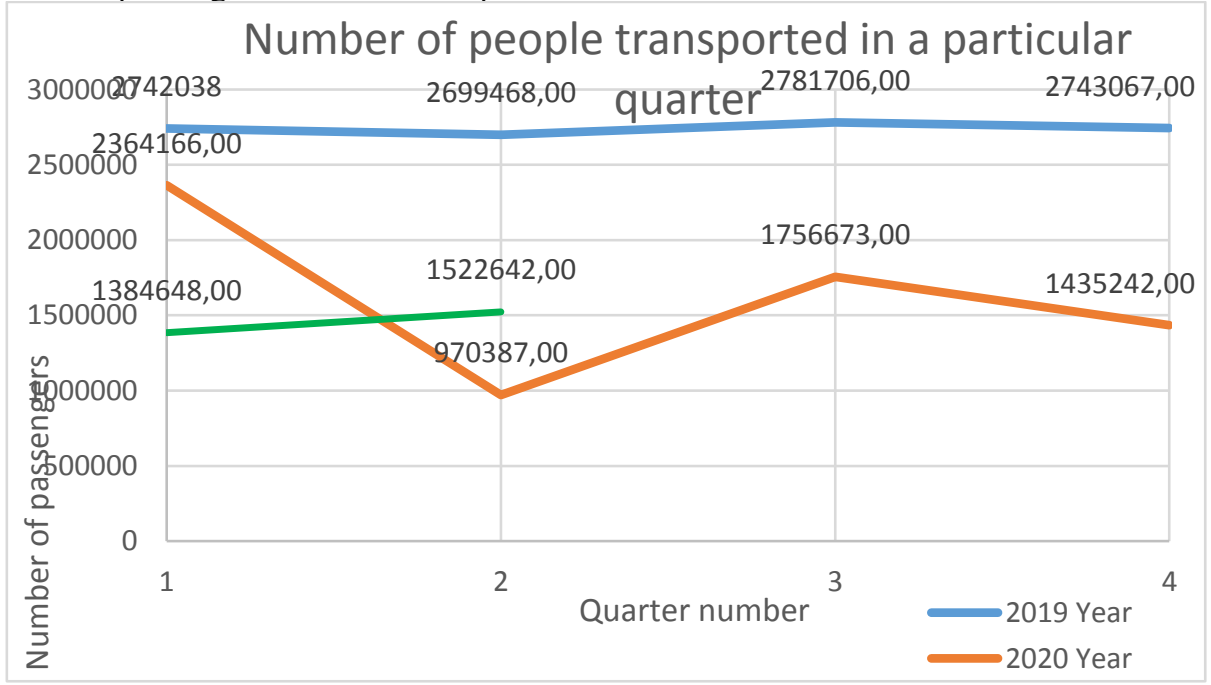

Fig. 3. Decrease in the number of passengers using public transport - comparison of individual quarters of 2019, 2020 and 2021. 
Computer systems supporting maintenance services are being introduced more and more often in machine operation systems (in enterprises). One of the basic functions of computer programs supporting maintenance services is the registration of data on individual vehicle states. After implementing such systems, it is possible to automatically generate periodic reports containing various damage indicators, including indicators defined by software users [10-13].

\subsection{Analysis of the problem of modeling and control of operational processes}

The object of research is the generally understood system of machine operation. In this system, controlled processes are implemented, which are components of the operation process. The rationality of the operation of this system determines the effectiveness of the use of machines and the possibility of achieving the goals set by these machines [14].

The communication system carries out successively the tasks forming the work cycle: $\mathrm{fl}$ - the phase of activating the elements, $\mathrm{f} 2$ - the phase of task implementation, $\mathrm{f} 3$ - the maintenance phase, f4- organizational standstill (phase of waiting for commissioning)

In the phase of tasks f2, individual elementary subsystems of the $<$ C-OT $>$ type (driver - tram) perform the assigned transport tasks. Due to the possibility of damage to the tram or the driver's unfitness, the time of carrying out transport tasks by individual elementary subsystems is random.

In the tested operation system, the damaged tram is directed to the serviceability subsystem, where it undergoes renewal (servicing) processes during an epidemic, the situation in which a suspected person meets in the middle of public transport is also counted to such a state, and the bus must be disconnected from traffic and disinfected. before it becomes operational again [15-16].

After completion of the maintenance processes, the task-oriented vehicle is directed to the tasks or to the parking yard (if the vehicle cannot take up the task immediately after the service is completed due to the schedule of transport tasks implemented in the system). The duration of vehicle maintenance (the vehicle is in the airworthiness system) is random.

In order to restore, in the shortest possible time, the condition of the roadworthiness of vehicles that have been damaged during the implementation of transport tasks, the so-called technical emergency. The scope of service (repairs) performed by the operators of technical emergency units is limited by the existing technical equipment of these units and the necessity to perform service outside the premises of the service station. The time of recovery (by operators of technical emergency units) is also random [17-18].

The vehicle, which has been restored to its fit as a result of the actions of the operators of technical emergency units, is sent to the transport task (it takes up the interrupted task).

It is important in the aspect of ensuring the continuity of the performance of transport tasks and the technical and economic efficiency achieved by the system, that during the phase $\mathrm{f} 2$ of the working cycle, as many vehicles as possible are in the condition of taskworthiness and perform transport tasks. It is influenced by such factors as: the features of the vehicles in use, the type of equipment and the number of service stations at service stations and technical emergency units, the equipment of the technical emergency units with diagnostic equipment, the nature of the transport tasks performed, the manner and scope of service processes and others 11-12 ].

Thus, it is possible to influence the system's ability to perform the undertaken transport tasks. Therefore, there is a need to assess (forecast) the impact of actions taken in the system on the course of the operation process and the behavior of the system. 


\section{Summary}

Summing up the current economic situation of many enterprises, one should be careful about long-term macroeconomic forecasts and remember the concept of "black swans" (events for which there was not even a shadow of suspicion that they would occur - but they happened, which had huge consequences for the environment), because they happen more and more often and have an increasing territorial scope, and thus generate more and more financial losses [19].

Due to the pandemic, the average decrease in revenues from ticket sales - both in public transport and on railways - is estimated at over $80 \%$, but local governments, despite the existing difficulties, are investing in new solutions, e.g. electric buses and vehicles equipped with modern air conditioning systems, vehicle ozonation systems, in order to increase the comfort of passenger travel as much as possible.

The most important challenge for the coming years is to restore the trust of public transport passengers. Local governments try to carry out the necessary activities on their own, but apart from objective difficulties, there are numerous restrictions and disinformation policy.

\section{References}

1. https://www.who.int/emergencies/diseases/novel-coronavirus-2019 (accessed on 19/11/2021)

2. B. Landowski, M. Baran, Analysis of selected results of engine oil tests, MATEC Web of Conferences 302, 01010 (2019), 18th International Conference Diagnostics of Machines and Vehicles, pp.1-7 (2019),

3. B. Landowski, M. Baran, Analysis of changes in the value of selected lubricant characteristics during use, MATEC Web of Conferences 302, 01009 (2019), 18th International Conference Diagnostics of Machines and Vehicles, pp.1-8 (2019),

4. B. Landowski, Ł. Muślewski, Numerical simulation of stochastic process as a model of technical object state changes. Engineering Mechanics 2018 Proceedings, Vol 24 Book Series: Engineering Mechanics, 24nd International Conference, may 14 - 17, 2018, Svratka, Czech Republic, Book of full texts, Institute of Theoretical and Appiled Mechanics of the Czech Academy of Sciences, Prague, pp. 485-488 (2018)

5. M. Żółtowski, M. Liss, B. Żółtowski, J. Melcer, Truss harbor cranes modal design elements research, Polish Maritime Research, No 4 (88), Vol. 22, pp. 84-92 (2015)

6. M. Łukasiewicz, M. Liss, N. Dluhunovych, Analysis of vibrodiagnostics methods in the technical state study of designed multimedia mobile scenes, 18th International Conference Diagnostics of Machines and Vehicles, MATEC Web of Conferences, Vol. 302 (2019)

7. B. Landowski, Ł. Muślewski, M. Pająk, O. Polishchuk, Method for initial assessment of unit costs of public city transport means operation, MATEC Web of Conferences 182, 01010 (2018), 17th International Conference Diagnostics of Machines and Vehicles, pp.1-7 (2018),

8. Ł. Muślewski, L. Knopik, B. Landowski, O. Polishchuk, Analysis of assessment criteria for selected systems of transport means operation, MATEC Web of 
Conferences 182, 02003 (2018), 17th International Conference Diagnostics of Machines and Vehicles, pp.1-10 (2018),

9. B. Landowski, Ł. Muślewski, Decision model of an operation and maintenance process of city buses, Proceedings of 58th International Conference of Machine Design Departments - ICMD 2017, Publisher: Czech University of Life Sciences Prague, Czech Republic, pp. 188-193 (2017)

10. B. Landowski, D. Perczyński, Ł. Muślewski, P. Kolber, Economic aspects of a city transport means purchase. Proceedings of 58th International Conference of Machine Design Departments - ICMD 2017, Publisher: Czech University of Life Sciences Prague, Czech Republic, pp. 194-199 (2017)

11. B. Landowski, D. Perczyński, P. Kolber, Ł. Muślewski, An example of Markov model of technical objects maintenance process. Engineering Mechanics 2016 Proceedings, Vol 22 Book Series: Engineering Mechanics, 22nd International Conference, may 9 12, 2016, Svratka, Czech Republic, Book of full texts, Institute of Thermomechanics Academy of Sciences of the Czech Republic, pp. 346-349 (2016)

12. V. Martynyuk, J. Boiko, M. Łukasiewicz, E. Kuliś, J. Musiał, Diagnostics of Solar Cells, $18^{\text {th }}$ International Conference Diagnostics of Machines and Vehicles, MATEC Web of Conferences;Vol $302 ; 2261-236 \mathrm{X}$

13. J. Wilczarska, E. Kuliś, M. Łukasiewicz, Ł. Fornal, N. Dluhunovych, The assessment of the impact of the chosen exploational conditions of hydraulic arrangement on the working liquid condition, 17th International Conference Diagnostics of Machines and Vehicles, MATEC Web of Conferences, Vol. 182 (2018)

14. Ł. Muślewsk, E. Kuliś, B. Landowski, Model of the process of operating rail transport means, Engineering Mechanics 2020 Proceedings, Vol 26 Book Series: Engineering Mechanics, 26nd International Conference, November 24 - 25, 2020, Svratka, Czech Republic, Book of full texts, Institute of Theoretical and Appiled Mechanics of the Czech Academy of Sciences, Prague, pp. 485-488 (2020)

15. V. Martynyuk, O. Eromenko, J. Boiko, T. Kałaczyński, Diagnostics of supercapacitors, 17th International Conference Diagnostics of Machines and Vehicles, Matec Web of Conferences 2018, 182, 1-10, Poland, (2018)

16. Red. J. Bieliński, P. Nogal-Meger, A. Szpa, Koncepcja „czarnych łabędzi” a zarządzanie ryzykiem finansowym, zarządzanie w przedsiębiorstwie i regionie. Nowe wyzwania. Wydawnictwo Wydział Zarządzania Uniwersytetu Gdańskiego, Sopot, p.49 (2015)

17. B. Landowski, Method of modelling operation and maintenance processes in public transport systems using a certain class of stochastic processes, MATEC Web of Conferences 332, 01005 (2021),

18. https://www.gdynia.pl/co-nowego,2774/bezpieczna-komunikacja-miejska,552642 (accessed on 15/11/2021)

19. B. Landowski, E. Kuliś, Impact of the epidemiological situation in Poland in 2020 on the public transport system, MATEC Web of Conferences 332, 01023 (2021),

20. https://mpk.com.pl (accessed on 15/11/2021) 